\title{
Influenza season 2019: analysis of 143 hospitalized cases
}

\author{
Indalecio Carboni Bisso ${ }^{1}$ Eduardo Prado ${ }^{1}$, Joaquin Cantos ${ }^{1}$, Agustín Massó ${ }^{1}$, Inés \\ Staneloni ${ }^{2}$, Eduardo San Román ${ }^{1}$, Iván Huespe ${ }^{1}$, Marcos Las Heras ${ }^{1}$ \\ ${ }^{1}$ Intensive Care Unit, Hospital Italiano de Buenos Aires \\ ${ }^{2}$ Infectious Diseases, Hospital Italiano de Buenos Aires
}

\section{Corresponding author:}

indalecio.carbonibisso@hospitalitaliano.org.ar

Tte. Gral. J. D. Perón 4190 (C1199ABB) - Buenos Aires - Argentina

(+54 011) 4959-0200

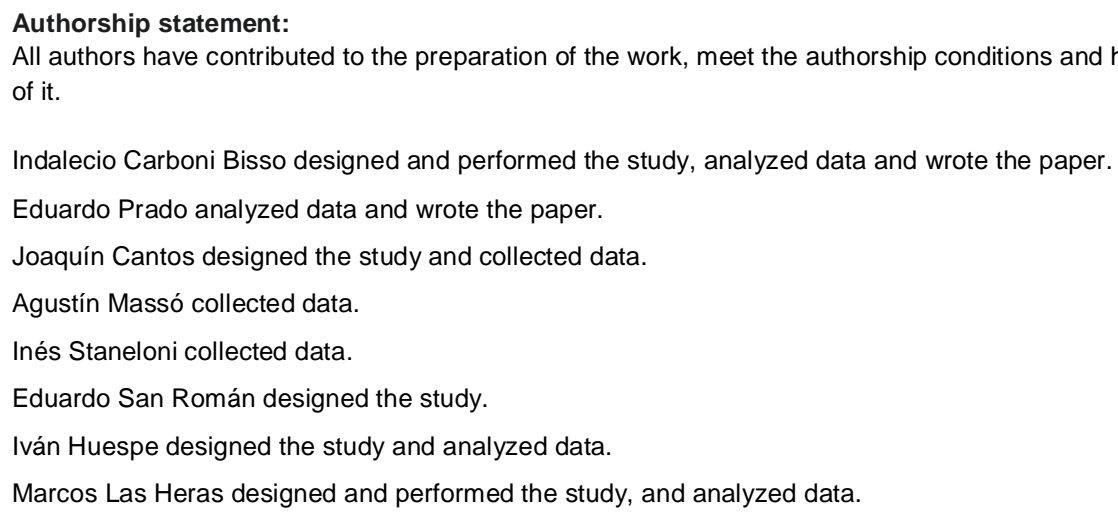

The authors declare that there is no conflict of interest regarding the publication of this article. 


\section{ABSTRACT}

Introduction

Influenza virus infection is a latent public health problem, affecting millions of people through the planet, and it is an important cause of morbidity and mortality. In Argentina, there is a significant absence of data regarding influenza severe respiratory disease and, therefore, a lack of knowledge about the impact of this disease at health institutions.

\section{Objectives}

Analysis of clinical characteristics, image findings and laboratory variables in patients with influenza viruses during 2019.

\section{Methods}

Retrospective, single-centre study, we analyzed all confirmed cases of influenza in a high complexity hospital from Buenos Aires.

\section{Results}

143 patients with influenza virus were hospitalized in this period of time. The $98.6 \%$ were infected by type A influenza, and most of them $61.5 \%$ were $\mathrm{H} 1 \mathrm{~N} 1$ subtype.

Median age was 71 years (IQR 60 - 82), 77.6\% were older than 70 years, and $88.1 \%$ had at least one coexisting illness. $39.1 \%$ of the patients required intensive care, $11.1 \%$ invasive mechanical ventilation and $4.1 \%$ died during hospitalization.

\section{Conclusion}

Mortality and severity were similar to previous series of non-pandemic influenza. Analysis of annual data would be valuable in order to document the severity of influenza hospitalizations by age - group and comorbidities according to the circulating influenza viruses. 


\section{INTRODUCTION}

Influenza virus infection is a latent public health problem, affecting millions of people through the planet, and it is an important cause of morbidity and mortality, especially for certain susceptible populations.

Influenza virus is a single stranded RNA virus, characterized by 4 types ( $A, B, C$ and $D)$. This virus has 2 important surface glycoproteins, hemagglutinin $(\mathrm{H} 1, \mathrm{H} 2$ and $\mathrm{H} 3$, the most common in humans) and neuraminidase (N1 and N2, the most common in humans), which are used to classify the different subtypes and give the virus a changing antigenicity as its main characteristic. The term "antigenic drift" makes reference to the periodic changes in the antigenicity of the virus that occur year by year, while "antigenic shift" describes the generation of large genetic recombinations which are responsible for pandemics, such as the one that took place in $2009^{1}$.

Influenza infection can evolve, due to the same pathogenicity of the virus or bacterial superinfection, into a severe respiratory infection. Among the risk factors for presenting a severe influenza disease, it is possible to recognise increasing age, cardiovascular disease, malignancy, immunosuppression, hypertension, neuromuscular disease, diabetes mellitus, chronic lung, liver, or metabolic renal disease. Also obesity and pregnancy were associated with increased risk of negative outcomes in some studies ${ }^{2,3}$.

Among the patients hospitalized due to influenza severe respiratory infection, it has been estimated that 29 to $6 \%$ require admission to the intensive care unit (ICU). A recent multicentre European study which analyzed the characteristics and outcomes of hospitalized patients with diagnosis of influenza from 2009 to 2017 reported that $43 \%$ of the patients admitted to the ICU did not have predisposing factors and $21 \%$ of hospital mortality.

In Argentina, there is a significant absence of data regarding influenza severe respiratory disease and, therefore, a lack of knowledge about the impact of this disease at health institutions, hospital mortality, and the profile of patients requiring ICU. Thus, the objective of this work is to describe the history of comorbidities as well as the clinical, laboratory and imaging findings of patients who required hospitalization in a general ward or ICU during 2019 in a high-complexity care hospital from Buenos Aires, capital of Argentina.

\section{METHODS}

In this retrospective, observational single-centre study, we included patients from January 1 to December 312019 at a high complexity hospital from Buenos Aires. The study was approved by the Ethics Committee from our hospital in October 2019.

\section{Data sources}


We obtained epidemiological, demographic, clinical, laboratory, management, and outcome data from patients' medical records. Clinical outcomes were followed up to march, 2020.

\section{Procedures}

Throat-swab specimens from the upper respiratory tract that were obtained from all patients at admission were maintained in viral-transport medium. Influenza and other respiratory viruses including adenovirus, respiratory syncytial virus, parainfluenza viruses, rhinovirus, enterovirus, coronavirus and bocavirus were confirmed by using real time reverse transcription polymerase chain reaction (real time RT-PCR). Due to sequence similarity, rhinovirus and enterovirus may not be discriminated by the technique used. Sputum or endotracheal aspirates were obtained at admission for identification of possible causative bacteria or fungi. Additionally, all patients were given chest $\mathrm{x}$-rays or chest computed tomography scans (CTs).

\section{Outcomes}

We describe epidemiological data, demographics, signs and symptoms on admission, comorbidity, laboratory results; co-infection with other respiratory pathogens, chest radiography and CT findings, treatment received and clinical outcomes.

\section{Statistical analysis}

Continuous variables were expressed as medians and interquartile ranges or simple ranges, as appropriate. Categorical variables were summarized as counts and percentages. No imputation was made for missing data. Because the cohort of patients in our study was not derived from random selection, all statistics are deemed to be descriptive only. We used RStudio developed by R-Tools Technology Inc for all analyses. 


\section{RESULTS}

143 patients with influenza were included in this study, 79 patients were female and 64 men. Median age was 71 years (IQR 60 - 82). Among the overall population, 77.6\% (111) were older than 70 years, and $88.1 \%$ (126) had at least one coexisting illness. Chronic obstructive pulmonary disease (COPD) was the most frequently observed $(30.0 \%)$, followed by immunosuppression (27.2\%) and cardiovascular disease (19.5\%). 56 patients (39.9\%) required ICU admission and the rest of them were treated in general ward. 16 patients (11.1\%) underwent invasive mechanical ventilation (iMV), 40 (27.9\%) non invasive ventilation or high-flow nasal cannula and 6 patients $(4.1 \%)$ died during hospitalization. Furthermore, 5 patients (9\%) hospitalized in ICU died.

Vaccination status was known in all cases, with a vaccination rate of $32.1 \%$ (28) in non-ICU patients and $26.7 \%$ (15) in ICU patients. $6.9 \%$ (3) of vaccinated patients required iMV vs. $13 \%$ (13) of the unvaccinated cases. The median hospitalization time was 7 days (IQR 4 13) for all patients, 5 days (IQR 3 - 10) for non-ICU patients and 10 days (IQR 6 - 16) for ICU cases. Demographic and clinical characteristics of patients are shown in Table 1.

Influenza viruses were detected by real-time RT-PCR. 98.6\% of patients were infected by type A influenza, $61.5 \%$ had subtype $\mathrm{H} 1 \mathrm{~N} 1$ and $37.0 \% \mathrm{H} 3 \mathrm{~N} 2$. Most of the cases were reported during the 24th to 32 nd epidemiological weeks of winter season in the Southern hemisphere. Annual distribution of the cases is detailed in Figure 1 and the distribution of cases by viral type and subtype in Figure 2.

Regarding clinical findings, fever was present on admission in $65.0 \%$ (93) of the patients. The second most common symptom was shortness of breath $(58.0 \%)$, followed by cough $(52.4 \%)$ and rhinorrhoea (19.5\%) diarrhoea, nausea or vomiting $(4.8 \%)$ were uncommon. Also dyspnoea was more frequent in ICU patients (69.6\% vs. $50.5 \%$ ).

Among laboratory findings, lymphocytopenia was present in $64.3 \%$ of the patients, leukocytosis in $35.6 \%$ and neutrophilia in $24.4 \%$. Hyponatremia was found in $46.1 \%$ of the patients, and $28.6 \%$ presented elevated serum creatinine and urea. Half of the patients [50.0\% (28)] who underwent admission to ICU presented elevated serum pro b-type natriuretic peptide (proBNP) (median $2044 \mathrm{pg} / \mathrm{ml}$, IQR 781 - 4904) that was also elevated in $12.6 \%(11)$ of the non-ICU patients. In addition, elevation of serum transaminases was more frequently seen in ICU patients (37,5\% vs. $8.0 \%)$, without associated involvement of alkaline phosphatase, bilirubin or prothrombin time. Table 2 shows clinical presentation and laboratory findings. 
Of 129 chest $x$-rays that were performed at the time of admission, $67.4 \%$ revealed abnormal results. The most common patterns shown were: interstitial opacity $(35.6 \%)$, consolidation $(24.8 \%)$ and pleural effusion (6.9\%). Also, 33.3\% of the patients presented bilateral compromise. Moreover, almost the total of ICU cases [98.1\% (50)] showed pathological findings in chest $x$-rays in contrast with admissions to general ward [47.4\% (37)].

85 chest CTs were performed. No CTs abnormality was found in 11 (12.9\%) studies. Ground-glass opacity was found in $34.1 \%$, followed by consolidation in $29.4 \%$, tree in bud sign in $15.2 \%$, and multiple mottling opacity in $8.2 \%$. In addition, bilateral compromise was informed in $44.7 \%$ and pleural effusion in $14.1 \%$. Furthermore, bilateral compromise was more frequent among ICU patients compared with non-ICU patients in both chest x-rays $[50.9 \%(26)$ vs. $21.7 \%(17)]$ and chest CTs $[67.6 \%$ (23) vs. $29.4 \%(15)]$. Table 3 shows images findings. 


\section{DISCUSSION}

In this cohort study, we reported the clinical characteristics and risk factors associated with clinical outcomes in patients with laboratory-confirmed influenza who required hospitalization during 2019. We found that overall mortality was similar to previous series. However, in ICU cases, mortality was significantly lower ( $9 \%$ vs. 10 to $31 \%$ range), despite the fact that the majority of the cases reported in this study were older than 70 years and had at least one coexisting illness ${ }^{4-6}$. Also, the relative amount of patients admitted to ICU was higher. This may be attributed to the ICU criteria of our unit, where age is not a restriction for invasive vital support. Nevertheless, it is important to point out the lack of post-ICU follow up, therefore, we do not evaluate cognitive, emotional or physical status after discharge.

In this series, vaccination acted as a protective factor against severe illness, with less ICU admission, less iMV requirement and a decreased length of stay. It is well documented that influenza vaccines provide substantial protection against severe influenza illness among adults. But also, they seem to provide low protection for elderly patients in seasons where vaccine and circulating $A(H 3 N 2)$ strains were antigenically variant ${ }^{7,8}$. During 2019 , a double viral circulation was registered in Argentina with the presence of subtypes H1N1 and H3N2. These findings should be taken into account to improve vaccination strategies and achieve better vaccination coverage in order not only to decrease flu cases, but also their severity.

As regards chronic medical illnesses, we found a lower quantity of immunosuppressed patients in ICU against the group that required hospitalization in general ward $(14.6 \%$ vs. $33.3 \%$ ). Additionally, mortality was higher among immunocompetent patients $(3.8 \%$ vs. $0.5 \%$ ) with no difference in median length of stay or $\mathrm{MMV}$ requirement. In this sense it is reported that a lower inflammatory response in immunosuppressed patients against the pathogen is associated with better outcomes and less organic failure ${ }^{9,10}$. It is interesting to analyze the behavior of influenza in immunosuppressed patients in order to draw conclusions and extrapolate information to the general of this population. However, we believe that it is worth highlighting these findings that we mentioned in order to inform professionals and undertake future research.

In relation to the laboratory findings, hepatic enzymes impairment, mainly ASAT, was far more frequent in ICU cases than in general patients. In a recently published research, ASAT rate superior to $68 \mathrm{IU} / \mathrm{L}$ was identified as a predictor of 3-month mortality with other variables such as creatinine and $\mathrm{PaO} 2 / \mathrm{FiO} 2$ with a hazard ratio (HZR) of 7.68 (IC 95\% 1.6-35.1), the highest HZR among them ${ }^{11}$. Additionally, proBNP was higher in ICU patients (median 2044 $\mathrm{pg} / \mathrm{mL}$, IQR 781 - 4904 vs. 1361, IQR 537 - 2341), in fact $50.0 \%$ of critical patients had 
values higher than normal range $(210 \mathrm{pg} / \mathrm{mL})$ vs. $12.6 \%$ of non ICU patients. ProBNP has been reported to be useful as a predictor in patients with confirmed influenza ${ }^{12}$.

Regarding images studies, it is important to pinpoint that in our series only one patient of those who required critical care had a normal result. Likewise, greater radiological impact was seen in ICU cases, with more bilateral compromise in both chest x-rays $(50.9 \%$ vs. $21.7 \%)$ and chest CTs (26.4\% vs. $5.8 \%$ ) in comparison with non-ICU patients. Similar data was found in other series where a high percentage of pathological radiographic findings were detected in patients with a worse prognosis ${ }^{13-15}$.

Our study has several limitations. It is an observational study of a single center and data from other Argentine centers are necessary to know the impact of the influenza in hospitalizations. Also, as previously noted, no post-ICU follow up was performed.

Regarding the behavior of the virus in 2019 , we conclude that both mortality and severity of the cases were similar to those published in previous series of non-pandemic influenza. Analysis of annual data would be valuable in order to document the severity of influenza hospitalizations by age $\square$ group and comorbidities according to the circulating influenza viruses. 


\section{REFERENCES}

1. Leveau CM, Uez O, Vacchino MN. Spatiotemporal trends of cases of pandemic influenza A(H1N1)pdm09 in Argentina, 2009-2012. Rev Inst Med Trop Sao Paulo. 2015;57(2):133-138.

2. Van Kerkhove MD, Vandemaele KAH, Shinde V, et al. Risk Factors for Severe Outcomes following 2009 Influenza A (H1N1) Infection: A Global Pooled Analysis. PLoS Medicine. 2011;8(7):e1001053. doi:10.1371/journal.pmed.1001053

3. Mertz D, Kim TH, Johnstone J, et al. Populations at risk for severe or complicated influenza illness: systematic review and meta-analysis. BMJ. 2013;347(aug23 1):f5061f5061. doi:10.1136/bmj.f5061

4. Pivette M, Nicolay N, de Lauzun V, Hubert B. Characteristics of hospitalizations with an influenza diagnosis, France, 2012-2013 to 2016-2017 influenza seasons. Influenza Other Respi Viruses. 2020;14(3):340-348.

5. Vandroux D, Allyn J, Ferdynus C, et al. Mortality of critically ill patients with severe influenza starting four years after the 2009 pandemic. Infect Dis. 2019;51(11-12):831837.

6. Ao T, McCracken JP, Lopez MR, et al. Hospitalization and death among patients with influenza, Guatemala, 2008-2012. BMC Public Health. 2019;19(S3).

doi:10.1186/s12889-019-6781-6

7. Rondy M, El Omeiri N, Thompson MG, Levêque A, Moren A, Sullivan SG.

Effectiveness of influenza vaccines in preventing severe influenza illness among adults:

A systematic review and meta-analysis of test-negative design case-control studies. $J$ Infect. 2017;75(5):381-394.

8. Belongia EA, Simpson MD, King JP, et al. Variable influenza vaccine effectiveness by subtype: a systematic review and meta-analysis of test-negative design studies.

Lancet Infect Dis. 2016;16(8):942-951.

9. Stahl K, Seeliger B, Busch M, et al. Maintenance Immunosuppression Is Associated With Better Outcome in the 2017/2018 Influenza Epidemic. Open Forum Infect Dis. 2019;6(10):ofz381.

10. Seeliger B, Stahl K, Busch M, et al. Immunosuppression is associated with lower morbidity and mortality in the $2017 / 2018$ influenza epidemic. Respiratory infections. 2019. doi:10.1183/13993003.congress-2019.pa4561

11. Abaziou T, Delmas C, Vardon Bounes F, et al. Outcome of Critically III Patients With Influenza Infection: A Retrospective Study. Infect Dis. 2020;13:1178633720904081.

12. Valero Cifuentes S, García Villalba E, Alcaraz García A, et al. Prognostic value of pro-adrenomedullin and NT-proBNP in patients referred from the emergency department with influenza syndrome. Emergencias. 2019;31(3):180-184.

13. Schoen K, Horvat N, Guerreiro NFC, de Castro I, de Giassi KS. Spectrum of clinical and radiographic findings in patients with diagnosis of $\mathrm{H} 1 \mathrm{~N} 1$ and correlation with clinical severity. BMC Infect Dis. 2019;19(1):964.

14. Henzler T, Meyer M, Kalenka A, et al. Image findings of patients with H1N1 
medRxiv preprint doi: https://doi.org/10.1101/2020.09.16.20195974; this version posted September 18, 2020. The copyright holder for this preprint (which was not certified by peer review) is the author/funder, who has granted medRxiv a license to display the preprint in perpetuity.

It is made available under a CC-BY 4.0 International license .

virus pneumonia and acute respiratory failure. Acad Radiol. 2010;17(6):681-685.

15. Rostami M, Javadi A-A, Khorvash F, et al. Thoracic computerized tomographic (CT) findings in 2009 influenza A (H1N1) virus infection in Isfahan, Iran. $J$ Res Med Sci. 2011;16(5):591-597. 
medRxiv preprint doi: https://doi.org/10.1101/2020.09.16.20195974; this version posted September 18, 2020. The copyright holder for this preprint (which was not certified by peer review) is the author/funder, who has granted medRxiv a license to display the preprint in perpetuity.

It is made available under a CC-BY 4.0 International license .

\section{Annual distribution}

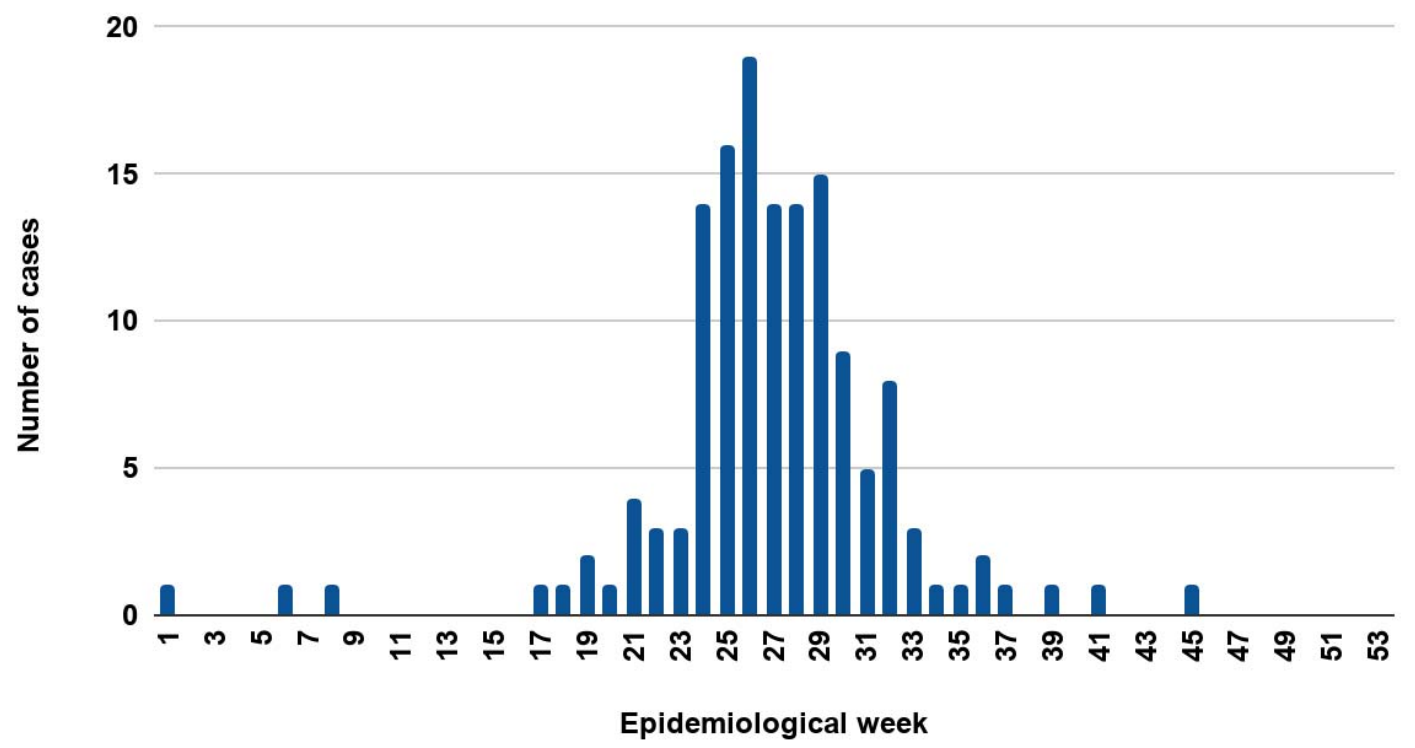

Figure 1. Annual distribution of influenza cases. 
medRxiv preprint doi: https://doi.org/10.1101/2020.09.16.20195974; this version posted September 18, 2020. The copyright holder for this preprint (which was not certified by peer review) is the author/funder, who has granted medRxiv a license to display the preprint in perpetuity.

It is made available under a CC-BY 4.0 International license .

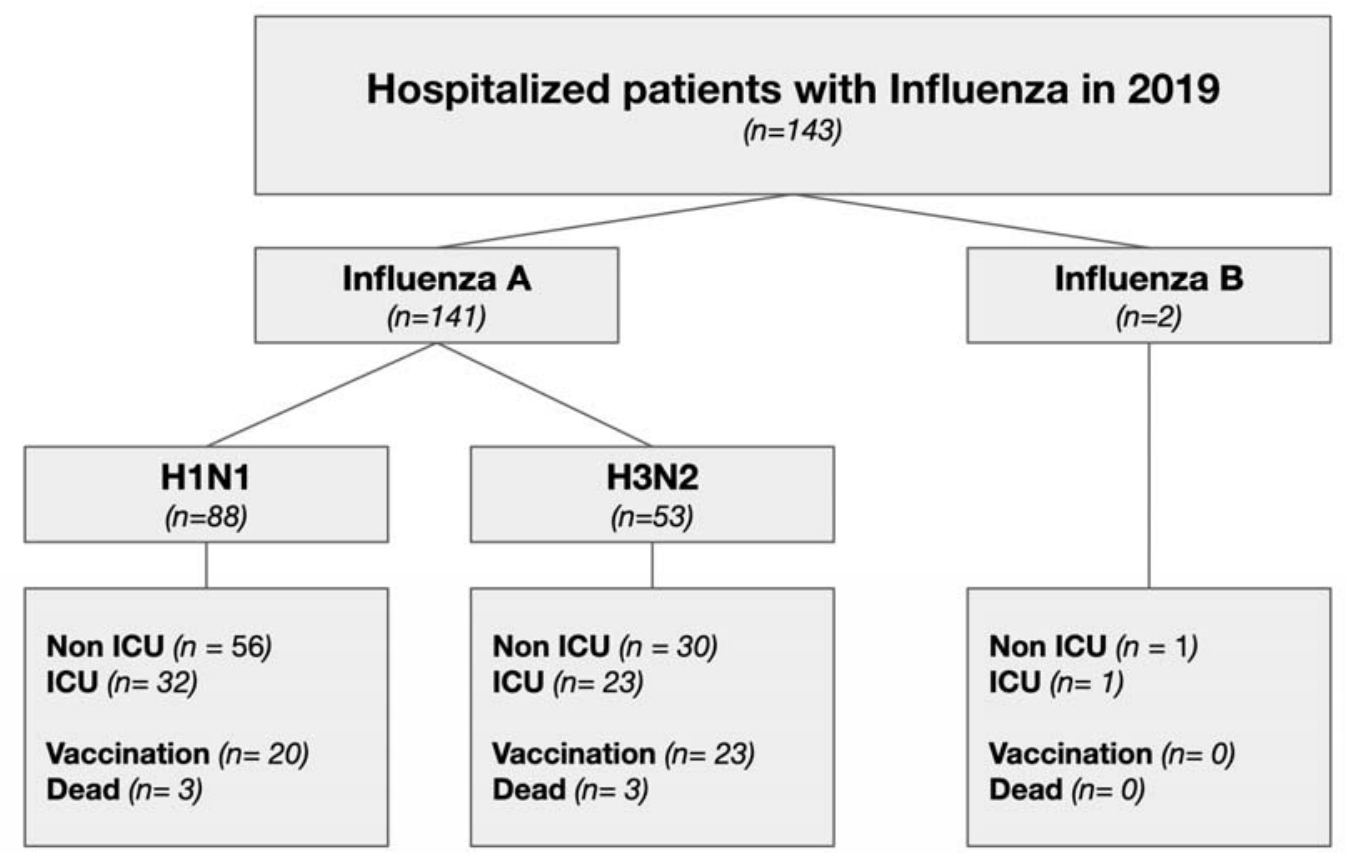

Figure 2. Distribution of cases by viral type and subtype. 
medRxiv preprint doi: https://doi.org/10.1101/2020.09.16.20195974; this version posted September 18, 2020. The copyright holder for this preprint (which was not certified by peer review) is the author/funder, who has granted medRxiv a license to display the preprint in perpetuity.

It is made available under a CC-BY 4.0 International license .

TABLES

\begin{tabular}{|c|c|c|c|}
\hline & $\begin{array}{l}\text { All patients } \\
(\mathrm{n}=143)\end{array}$ & $\begin{array}{c}\text { ICU } \\
(n=56)\end{array}$ & $\begin{array}{l}\text { non-ICU } \\
(\mathrm{n}=87)\end{array}$ \\
\hline \multicolumn{4}{|l|}{ Sex, male } \\
\hline \% (total no.) & $44.7 \%(64)$ & $41.1 \%(23)$ & $47.2 \%(41)$ \\
\hline \multicolumn{4}{|l|}{ Age, years } \\
\hline $\begin{array}{l}\text { Median (IQR) - yr } \\
\text { Distribution - \% (no.) }\end{array}$ & $71(60-82)$ & $74(72-84)$ & $69(58-80)$ \\
\hline$\leq 39 \mathrm{yr}$ & $8.3 \%(12)$ & $3.5 \%(2)$ & $11.4 \%(10)$ \\
\hline $\begin{array}{l}40-59 \mathrm{yr} \\
60-79 \mathrm{yr}\end{array}$ & $\begin{array}{l}13.9 \%(20) \\
45.4 \%(65)\end{array}$ & $\begin{array}{l}14.2 \%(8) \\
44.6 \%(25)\end{array}$ & $\begin{array}{l}13.7 \%(12) \\
45.9 \%(40)\end{array}$ \\
\hline$\geq 80 \mathrm{yr}$ & $32.1 \%(46)$ & $37.5 \%(21)$ & $28.7 \%(25)$ \\
\hline Chronic illness \% (no.) & $88.1 \%(126)$ & $78.5 \%(44)$ & $93.1 \%(81)$ \\
\hline COPD & $30.0 \%(43)$ & $23.2 \%(13)$ & $34.4 \%(30)$ \\
\hline Immunosuppression & $27.2 \%(39)$ & $14.6 \%(8)$ & $33.3 \%(29)$ \\
\hline Cardiovascular disease & $19.5 \%(28)$ & $28.5 \%(16)$ & $14.9 \%(13)$ \\
\hline Asthma & $11.1 \%(16)$ & $12.5 \%(7)$ & $10.3 \%(9)$ \\
\hline \multicolumn{4}{|c|}{ Vaccination status - \% (no.) } \\
\hline Non vaccinated & $69.9 \%(100)$ & $73.2 \%(41)$ & $67.8 \%(59)$ \\
\hline Vaccinated & $30.0 \%(43)$ & $26.7 \%(15)$ & $32.1 \%(28)$ \\
\hline \multicolumn{4}{|c|}{ Ventilatory support - \% (no.) } \\
\hline Invasive & $11.1 \%(16)$ & $28.5 \%(16)$ & - \\
\hline Non invasive & $27.9 \%(40)$ & $53.5 \%(30)$ & $11.4 \%(10)$ \\
\hline $\mathrm{NIV}^{*}$ & $16.7 \%(24)$ & $30.3 \%(17)$ & $8.0 \%(7)$ \\
\hline HFNC ** & $11.1 \%(16)$ & $23.2 \%(13)$ & $3.4 \%(3)$ \\
\hline \multicolumn{4}{|l|}{ Clinical outcome - \% (no.) } \\
\hline Discharged & $95.8 \%(137)$ & $91.0 \%(51)$ & $98.8 \%(86)$ \\
\hline Dead & $4.1 \%(6)$ & $9.0 \%(5)$ & $1.2 \%(1)$ \\
\hline
\end{tabular}

Table 1. Patients characteristics.

${ }^{*}$ Non-invasive ventilation

** High flow nasal cannula 
medRxiv preprint doi: https://doi.org/10.1101/2020.09.16.20195974; this version posted September 18, 2020. The copyright holder for this preprint (which was not certified by peer review) is the author/funder, who has granted medRxiv a license to display the preprint in perpetuity.

It is made available under a CC-BY 4.0 International license .

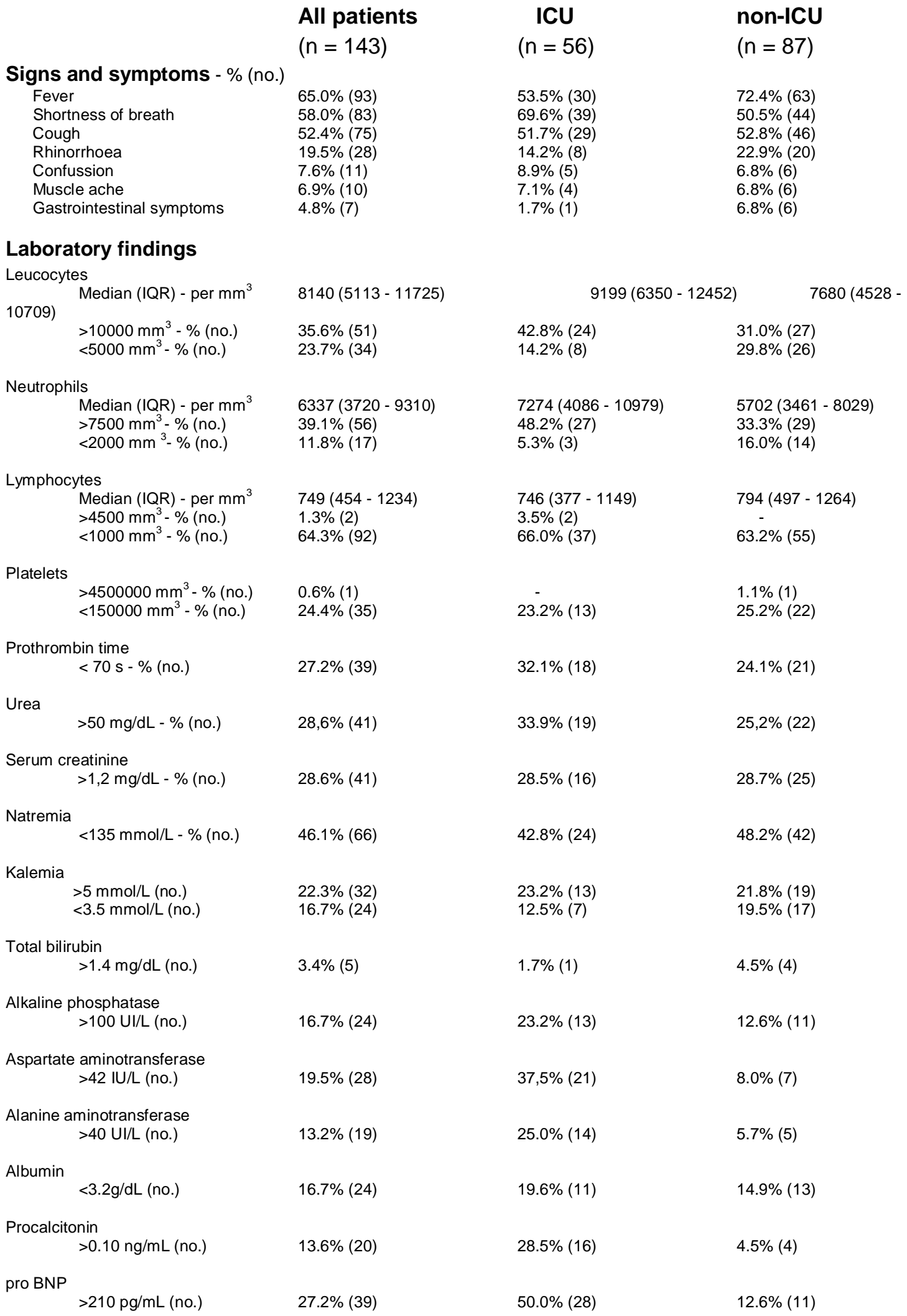

Table 2. Clinical presentation and laboratory findings. 
medRxiv preprint doi: https://doi.org/10.1101/2020.09.16.20195974; this version posted September 18, 2020. The copyright holder for this preprint (which was not certified by peer review) is the author/funder, who has granted medRxiv a license to display the preprint in perpetuity.

It is made available under a CC-BY 4.0 International license .

\begin{tabular}{|c|c|c|c|}
\hline & $\begin{array}{l}\text { All patients } \\
(n=129)\end{array}$ & $\begin{array}{c}\text { ICU } \\
(n=51)\end{array}$ & $\begin{array}{l}\text { non-ICU } \\
(n=78)\end{array}$ \\
\hline \multicolumn{4}{|l|}{ Chest $x$-ray findings - \% (no.) } \\
\hline Normal & $32.5 \%(42)$ & $1.9 \%(1)$ & $52.5 \%(41)$ \\
\hline Pathological & $67.4 \%(87)$ & $98.1 \%(50)$ & $47.4 \%(37)$ \\
\hline Interstitial opacity & $35.6 \%(46)$ & $50.9 \%(26)$ & $25.6 \%(20)$ \\
\hline Consolidation & $24.8 \%(32)$ & $35.2 \%(18)$ & $17.9 \%(14)$ \\
\hline Pleural effusion & $6.9 \%(9)$ & $11.6 \%(6)$ & $3.8 \%(3)$ \\
\hline \multirow[t]{2}{*}{ Bilateral compromise } & $33.3 \%(43)$ & $50.9 \%(26)$ & $21.7 \%(17)$ \\
\hline & $\begin{array}{l}\text { All patients } \\
(\mathrm{n}=85)\end{array}$ & $\begin{array}{c}\text { ICU } \\
(n=34)\end{array}$ & $\begin{array}{l}\text { non-ICU } \\
(n=51)\end{array}$ \\
\hline \multicolumn{4}{|l|}{ Chest CT findings - \% (no.) } \\
\hline Normal & $12.9 \%(11)$ & $2.9 \%(1)$ & $19.6 \%(10)$ \\
\hline Pathological & $87.0 \%(74)$ & $97.0 \%(33)$ & $80.3 \%(41)$ \\
\hline Ground-glass opacity & $34.1 \%(29)$ & $41.1 \%(14)$ & $29.4 \%(15)$ \\
\hline Consolidation & $29.4 \%(25)$ & $38.2 \%(13)$ & $23.5 \%(12)$ \\
\hline Tree-in-bud sign & $15.2 \%(13)$ & $11.7 \%(4)$ & $17.6 \%(9)$ \\
\hline Multiple mottling opacity & $8.2 \%(7)$ & $5.8 \%(2)$ & $9.8 \%(5)$ \\
\hline Bilateral compromise & $44.7 \%(38)$ & $67.6 \%(23)$ & $29.4 \%(15)$ \\
\hline Pleural effusion & $14.1 \%(12)$ & $26.4 \%(9)$ & $5.8 \%(3)$ \\
\hline
\end{tabular}

Table 3. Images findings. 